\title{
ГІДРОБІОЛОГІЯ
}

УДК [574.63:574.587](285.3)

doi: $10.25128 / 2078-2357.19 .3 .6$

\author{
О. А. ДАВИДОВ, Д. П. ЛАРІОНОВА \\ Інститут гідробіології НАН України \\ пр-т. Героїв Сталінграда, 12, Київ 04210 \\ e-mail: davydovoleg01@gmail.com
}

\section{САНІТАРНО-ГІДРОБІОЛОГІЧНА ХАРАКТЕРИСТИКА ОЗЕРА ВЕРБНЕ ЗА МІКРОФІТОБЕНТОСОМ}

За кількісними показниками мікрофітобентосу представлена санітарно-гідробіологічна характеристика озера Вербне, що зазнає антропогенного впливу м. Київ. 3' ясована суттєва роль бентонтів у формуванні індикаторних показників мікрофітобентосу. Результати досліджень дозволили класифікувати якість вод у літоральній зоні водойми та встановити, що у літній період відбувається зниження інтенсивності процесів самоочищення та погіршення стану водної екосистеми.

Ключові слова: мікрофітобентос, біоіндикачія, санітарно-гідробіологічна характеристика, міська водойма.

На території м. Києва розташовано більше 300 водойм різних за генезисом, морфометричними параметрами, ступенем антропогенного навантаження на їх екосистеми [4]. Основними наслідками антропогенного впливу $\epsilon$ зміна їх гідроморфометричних параметрів та гідрологічного режиму, забруднення розсіяним поверхневим стоком з території міста, точкових джерел, інтенсивне рекреаційне використання. Це обумовлює трансформацію структурних та кількісних показників різних угруповань гідробіонтів.

Одним із пріоритетних завдань сучасної санітарної гідробіології $є$ характеристика еколого-санітарного стану водних екосистем (у тому числі їх трофо-сапробіологічного статусу) та його порушення за дії антропогенних факторів. Санітарно-гідробіологічні дослідження зазвичай виконуються у два етапи: перший передбачає загальну характеристику, другий оцінку еколого-санітарного стану водних об'єктів [13].

Мікрофітобентос широко використовується для санітарно-гідробіологічної характеристики водних об'єктів, оскільки його біоіндикаційні можливості загальновідомі [12]. 3 широкого набору дескрипторів мікрофітобентосу найбільш інформативними $є$ склад, структура, кількісні показники, дані щодо бентонтів, оскільки характеристика та оцінка базуються на резидентній біоті $[10,14]$. Крім загальноприйнятих для санітарногідробіологічної характеристики водних екосистем, застосовуються спеціальні підходи і методи, основний з яких - біоіндикація.

Застосування мікрофітобентосу при визначенні ступеня сапробності на основі аутбіоіндикації та порівняння отриманих результатів з відповідними величинами показників, наведеними у «Методиці встановлення i використання екологічних нормативів якості поверхневих вод суші та естуаріїв України» (Додаток 2, 4), дозволяє здійснити екологічну класифікацію якості вод за трофо-сапробіологічними (еколого-санітарними) критеріями та віднести їх до визначених категорій якості поверхневих вод $[8,9]$. 
Вивчення санітарно-гідробіологічного стану озера Вербне, яке зазнає антропогенного забруднення поверхневим та грунтовим стоком 3 території житлового масиву Оболонь м. Києва, було розпочато у 80-х роках минулого століття, коли проводились комплексні дослідження за гідрофізичними, гідрохімічними та гідробіологічними характеристиками. 3 екологічних угруповань гідробіонтів вивчались зоо- та бактеріопланктон, зообентос та фітопланктон [3]. Лише на початку XXI століття мікрофітобентосу як важливому компоненту його водної екосистеми почали приділяти належну увагу $[7,20]$. Проте, до сьогодні санітарногідробіологічна характеристика водойми за мікрофітобентосом не була представлена.

Мета роботи полягає у санітарно-гідробіологічній характеристиці та екологічній класифікації якості вод оз. Вербне за біоіндикаційними показниками мікрофітобентосу.

\section{Матеріал і методи досліджень}

Матеріалом слугували результати досліджень мікрофітобентосу оз. Вербне у 2017 р. Проби мікрофітобентосу відбирали весною, влітку і восени у літоральній зоні на глибині 0,5-1,0 м у трьох повторюваних місцях, вільних від заростей вищої водяної рослинності, 3 площі близько 40 см² $^{2}$ Кількісний підрахунок виконували на рахівній пластині у краплі об' ємом $0,1 \mathrm{~cm}^{3}$, відібраній штемпель-піпеткою. Для визначення діатомових водоростей виготовляли препарати з використанням спеціальних середовищ [15].

Таксономічна характеристика мікрофітобентосу наведена у відповідності до класифікаційної системи, прийнятої у флористичному зведенні [18].

У мікрофітобентосі автохтонні та алохтонні компоненти виділені з урахуванням характеристик приуроченості водоростей до певних біотопів $[1,2,5,6,11,17,19,21]$.

Показники мікрофітобентосу (видове багатство, чисельність, біомаса, домінуючий комплекс) проаналізовані у сезонному аспекті 3 конкретизацією отриманих даних про резидентну альгофлору та аутбіоіндикатори.

Індекс сапробності [16] розраховували за методом Пантле-Букк у модифікації Сладечека [22].

Трофічний статус водного об'єкту визначали за шкалами градацій величин показників біотичних угруповань $[8,10]$.

Екологічна класифікація якості вод за результатами біоіндикації сапробності (індексами сапробності) виконана за «Методикою встановлення і використання екологічних нормативів якості поверхневих вод суші та естуаріїв України» [9].

\section{Результати досліджень та їх обговорення}

За результатами досліджень мікрофітобентосу оз. Вербне встановлено, що навесні видове багатство мікрофітобентосу формувалось 40 внутрішньовидовими таксонами, що належали до 6 відділів. Основу його складали Bacillariophyta - 60,0\%, Chlorophyta та Euglenophyta були представлені у рівних частках - по 12,5\%, Cyanoprokaryota - 10,0\% видового різноманіття. Роль інших відділів незначна.

У структурі мікрофітобентосу за видовим багатством важлива роль належала автохтонним компонентам (облігатним та факультативним бентонтам), які налічували 20 видів і внутрішньовидових таксонів (50,0\%). Серед алохтонів більш представлені планктонти - 12 $(30,0 \%)$.

Кількісні показники мікрофітобентосу коливались у широких межах 45-1806 тис. кл/10 см² за чисельністю та 0,047-0,060 мг/10 см² за біомасою. Провідну роль у їх формуванні відігравали як бентонти (Aneumastus tusculus (Ehrenb.) D.G. Mann et Sticle, Oscillatoria agardhii Gom., O. amphibia Agardh), які були основними компонентами відповідного комплексу, так і планктонти (O. planctonica Wolosz., O. redekei van Goor.).

Результати аутбіоіндикації дозволили встановити, що у мікрофітобентосі індикатори сапробності представлені 22 видами (55,0\% видового багатства), які розподілялись між трьома основними $(\mathrm{o}, \beta, \alpha)$ та трьома перехідними $(\chi-\mathrm{o}, \mathrm{o}-\beta, \beta-0)$ зонами сапробності. Більшість 3 них $(59,1 \%)$ відносились до $\beta$-мезосапробних форм. Серед видів індикаторів переважали бентонти 45,5\%. Величина індексу сапробності коливалась у досить вузьких межах 1,62-1,63.

Влітку видове багатство мікрофітобентосу зменшувалось до 31 внутрішньовидового таксону, що належав до 5 відділів. Частка Bacillariophyta, які складали основу видового 


\section{ГІДРОБІОЛОГІЯ}

багатства, у порівнянні 3 весною була меншою і не перевищувала $41,9 \%$; натомість, частка Chlorophyta зростала до 22,6\%, частка Euglenophyta та Cyanoprokaryota - до 16,1\%.

У структурі мікрофітобентосу відбувались зміни у співвідношенні представників резидентної альгофлори та алохтонів - частка останніх зростала до $64,5 \%$, серед яких найбільш вагомий внесок належав планктонтам $-41,9 \%$.

Кількісні показники мікрофітобентосу коливались в межах 165-378 тис. кл/10 см² за чисельністю та 0,023-0,042 мг/10 $\mathrm{cm}^{2}$ за біомасою. На показники рясності мікрофітобентосу суттєво впливали алохтони, формуючи на дні озера до 68,7\% чисельності та 71,9\% біомаси. Така ситуація спостерігалась при інтенсивній вегетації у товщі води фітопланктону, який, осідаючи на дно, лімітував розвиток бентосних форм водоростей. За цих обставин основна роль у провідному комплексі належала саме планктонтам Aphanizomenon flos-aquae (L.) Ralfs, O. planctonica Wolosz., Trachelomonas volvochina Ehrenb., Pseudopediastrum boryanum var. longicorne Reinsch. 3 бентонтів високими показниками рясності вирізнялись O. agardhii та O. amphibia.

Кількість видів індикаторів сапробності у мікрофітобентосі у літній період зменшувалась до 16 (51,6\% видового багатства). Індикаторні види розподілялись між трьома основними (о, $\beta$, $\alpha)$ та двома перехідними (о- $\beta, \beta-\alpha)$ зонами сапробності, більшість 3 яких $(75,0 \%)$ відносились до $\beta$-мезосапробних форм. Частка бентонтів серед видів індикаторів не перевищувала $37,5 \%$. Величина індексу сапробності у цю пору року була найвищою і коливалась у межах $1,85-1,87$.

Восени видове багатство мікрофітобентосу у порівнянні з літнім періодом зростало до 39 внутрішньовидових таксонів, що належали до 5 відділів. Частка Bacillariophyta у видовому багатстві збільшувалась до $59,0 \%$ та зменшувалась до $15,4 \%$ у Chlorophyta, до $12,8 \%$ у Euglenophyta i 10,2\% y Cyanoprokaryota.

Автохтонні компоненти мікрофітобентосу налічували 17 внутрішньовидових таксонів (43,6\% від загальної кількості), серед алохтонів планктонти і перифітонти представлені у рівних частках - по $28,2 \%$.

Кількісні показники розвитку мікрофітобентосу були найбільшими за весь період досліджень та коливалась у межах 2844-2959 тис. кл/10 см² за чисельністю та 0,1380,209 мг/10 см² $^{2}$ за біомасою. Бентонти формували до 94,8\% чисельності та 87,9\% біомаси і були основою провідного комплексу мікрофітобентосу. На дні водойми домінували Amphora ovalis Kǘtz., Cymbella lanceolata (Ehrenb.) Kirch., Melosira varians Ag., Pseudostaurosira brevistriata (Grun.) Will. Et Round, O. amphibia, Phormidium foveolarum. Хоча, слід зазначити, що до його складу входили і планктонти Ap. flos-aquae, O. redekei, Desmodesmus communis (Turp.), Pediastrum duplex Meyen.

Кількість видів індикаторів сапробності мікрофітобентосу восени зростала у порівнянні 3 літнім періодом до 24 (61,5\% видового багатства), які розподілялись між трьома основними (о, $\beta, \alpha)$ та трьома перехідними (о- $\beta, \beta-о, \beta-\alpha)$ зонами сапробності. Переважна більшість 3 них $(54,1 \%) \beta$-мезосапробні форми, $\alpha$-мезосапробні форми у цю пору року характеризувались максимальними показниками $(20,8 \%)$. У структурі мікрофітобентосу частка бентонтів серед видів індикаторів збільшувалась до 48,5\%. Величина індексу сапробності, розрахована за мікрофітобентосом, зменшувалась у порівнянні з літнім періодом, але була вищою, ніж навесні, коливаючись у межах 1,74-1,83.

Таким чином, дослідження, проведені у весняно-осінній період, дозволили встановити, що за показниками рясності мікрофітобентосу трофність оз. Вербне відповідала мезотрофному класу і мезотрофному та мезо-евтрофному розрядам. Сапробність, в основному, відповідала $\beta$ мезосапробній зоні з тенденцією до олігосапробності.

Встановлено, що за екологічною класифікацією якості вод, виконаної за результатами біоіндикації сапробності (індексами сапробності) за мікрофітобентосом води оз. Вербне протягом усього періоду досліджень відносились до класу якості вод - II, категорії якості вод 3, категорії якості вод за їх станом - «добрі», категорії якості вод за ступенем їх чистоти (забрудненості) - «досить чисті». 


\section{Висновки}

Санітарно-гідробіологічна характеристика оз. Вербне за мікрофітобентосом визначає його, в цілому, як мезотрофний, $\beta$-мезосапробний водний об'єкт.

Чисельність та біомаса мікрофітобентосу характеризувались значною амплітудою коливань (45-2959 тис. кл/10 см² та 0,02-0,21 мг/10 см² відповідно), з найвищими показниками в осінній період. Домінуючий комплекс мікрофітобентосу полідомінантний. Бентонтам належала суттєва роль у формуванні індикаторних показників мікрофітобентосу. Серед видів індикаторів сапробності переважали $\beta$-мезосапробні форми. Величина індексу сапробності коливалась у межах 1,62-1,87.

Встановлено, що відповідно до екологічної класифікації якості вод найбільш несприятлива ситуація у літоральній зоні водоймі реєструється у літній період, що свідчить про зниження інтенсивності процесів самоочищення та погіршення стану водної екосистеми.

1. Баринова С. С., Медведева Л. А., Анисимова О. В. Биоразнообразие водорослей-индикаторов окружающей среды. Тель-Авив : Pilies Studio, 2006. 498 с.

2. Водоросли. Справочник / С. П. Вассер, Н. Б. Кондратьева, Н. П. Масюк и др. Киев : Наук. думка, 1989. $608 \mathrm{c}$.

3. Гидроэкологические проблемы внутренних водоемов Украины: сб. науч. тр. / отв. ред. О. М. Арсан. Киев: Наук. думка, 1991. 136 с.

4. Екологічний стан київських водойм. К. : Фітосоціоцентр, 2010. 256 с.

5. Кондратьєва Н. В., Коваленко О. В., Приходькова Л. П. Визначник прісноводних водоростей Української РСР. І. Синьозелені водорості. К. : Наук. думка, 1984. Ч. 1. 388 с.

6. Кондратьєва Н. В., Коваленко О. В., Приходькова Л. П. Визначник прісноводних водоростей Української РСР. І. Синьозелені водорості. К. : Наук. думка, 1984. Ч. 1. 388 с.

7. Ларіонова Д. П., Давидов О. А. Автохтонні компоненти озера Вербне. Біологічні дослідження 2018: збірник наукових праць. Житомир : ПП «Рута», 2018. С. 181-182.

8. Методи гідроекологічних досліджень поверхневих вод / за ред. В. Д. Романенка. К.: ЛОГОС, 2006. $408 \mathrm{c.}$

9. Методика встановлення і використання екологічних нормативів якості поверхневих вод суші та естуаріїв України / Романенко В. Д., Жукинський В. М., Оксіюк О.П. та ін. К., 2001. 48 с.

10. Оксиюк О. П., Давыдов О. А. Оценка экологического состояния водных объектов по микрофитобентосу. Киев : Институт гидробиологии НАНУ, 2006. 32 с.

11. Оксиюк О. П., Давыдов О. А., К Карпезо Ю. И Эколого-морфологическая структура микрофитобентоса. Гидробиол. журн. 2008. Т. 44, № 6. С. 15-27.

12. Оксиюк О. П., Давыдов О. А., Карпезо Ю. И. Микрофитобентос как биоиндикатор состояния водных экосистем. Гидробиол. журн. 2010. Т. 46, № 5. С. 75-89.

13. Оксиюк О. П., Давыдов О. А Санитарная гидробиология в современный период. Основные положения, методология, задачи. Гидробиол. журн. 2012. Т. 48, № 6. С. 50-65.

14. Семенченко В. П. Принципы и системы биоиндикации текучих вод. Минск: Opex, 2004. 125 с.

15. Топачевський О. В., Оксіюк О. П. Визначник прісноводних водоростей Української РСР. ХІ. Діатомові водорості. К.: Вид-во АН УРСР, 1960. 412 с.

16. Унифицированные методы исследования качества вод. Методы биологического анализа вод. М.: СЭВ, 1977. Прил. 1. Индикаторы сапробности. $91 \mathrm{c.}$

17. Царенко П. М. Краткий определить хлорококковых водоростей Украинской ССР. Киев: Наук. думка, 1990. $208 \mathrm{c}$.

18. Algae of Ukraine: diversity, nomenclature, taxonomy, ecology and geography / Ed. by P. M. Tsarenko, S. P. Wasser, E. Nevo. Ruggell: Ganter Verlag, 2006-2011. (Vol. 1. Cyanoprokaryota, Euglenophyta, Chrysophyta, Xanthophyta, Raphidophyta, Phaeophyta, Dinophyta, Cryptophyta, Glaucocystophyta and Rhodophyta. 2006. 713 p.; Vol. 2. Bacillariophyta. 2009. 413 p.; Vol. 3. Chlorophyta. 2011. 511 p.).

19. Bukhtiyarova L. Diatoms of Ukraine. Inland waters. Kyiv: National Academy of Science of Ukraine, 1999. $133 \mathrm{p}$.

20. Davydov O. A. Ecologic and morphological structure of microphytobenthos in Verbnoe lake (Ukraine). Матеріали Всеукраїнської міжнародної конференції «Актуальні проблеми альгології». Київ, 2019. C. $28-29$.

21. Krammer, Lange-Bertalot H. Bacillariophyceae. 1 - 4 Teile. Süsswasserflora von Mitteleuropa. 2/1 4. Stuttgart, Jena: VEB Gustav Fisher Verlag, 1986-1991. 876; 596; 576; 437 S. 
22. Sladeček V. System of water quality from the biological point of view. Ergebnisse der Limnologie. 1973. Vol. 7. P. 1-128.

\section{References}

1. Barinova S. S. Bioraznoobrazie vodorosley-indikatorov okruzhaiushchey sredy / Barinova S.S., Medvedeva L. A., Anisimova O. V. - Tel'-Aviv: Pilies Studio, 2006. - 498 s (in Russian).

2. Vodorosli. Spravochnik / S. P. Vasser, N. B. Kondrat'eva, N. P. Masiuk i dr. - Kiev: Nauk. dumka, 1989. 608 s (in Russian).

3. Gidroekologicheskie problemy vnutrennikh vodoemov Ukrainy: Sb. nauch. tr. / Otv. Red. O. M. Arsan. Kiev: Nauk. dumka, 1991. 136 s (in Russian).

4. Ekolohichnyy stan kyivs'kykh vodoym. - K.: Fitosotsiotsentr, 2010. - $256 \mathrm{~s}$ (in Ukrainian).

5. Kondrat'ieva N. V. Vyznachnyk prisnovodnykh vodorostey Ukrains'koi RSR. I. Syn'ozeleni vodorosti, ch. 1. / Kondrat'ieva N. V., Kovalenko O. V., Prykhod'kova L. P. - K.: Nauk. dumka, 1984. - 388 s (in Ukrainian).

6. Kondrat'ieva N. V. Vyznachnyk prisnovodnykh vodorostey Ukrains'koi RSR. I. Syn'ozeleni vodorosti, ch. 1. / Kondrat'ieva N. V., Kovalenko O. V., Prykhod'kova L. P. - K.: Nauk. dumka, 1984. - 388 s (in Ukrainian).

7. Larionova D. P. Avtokhtonni komponenty ozera Verbne / Larionova D. P., Davydov O. A. // Biolohichni doslidzhennia - 2018: Zbirnyk naukovykh prats'. - Zhytomyr: PP «Ruta», 2018. - S. 181- 182 (in Ukrainian).

8. Metody hidroekolohichnykh doslidzhen' poverkhnevykh vod / za red. V. D. Romanenka. - K.: LOHOS, 2006. - 408 s (in Ukrainian).

9. Metodyka vstanovlennia i vykorystannia ekolohichnykh normatyviv iakosti poverkhnevykh vod sushi ta estuariiv Ukrainy / Romanenko V. D., Zhukyns'kyy V. M., Oksiiuk O. P. ta in. - K., 2001. - 48 s (in Ukrainian).

10. Oksiiuk O. P. Otsenka ekologicheskogo sostoianiia vodnykh ob"ektov po mikrofitobentosu / Oksiiuk O. P,. Davydov O. A. - Kiev: Institut gidrobiologii NANU, 2006. - 32 s (in Russian).

11. Oksiiuk O. P. Ekologo-morfologicheskaia struktura mikrofitobentosa / Oksiiuk O. P., Davydov O. A., Karpezo Iu. I. // Gidrobiol. zhurn. - 2008. - T. 44, No6. - S. 15-27 (in Russian).

12. Oksiiuk O. P. Mikrofitobentos kak bioindikator sostoianiia vodnykh ekosistem / Oksiiuk O. P., Davydov O. A., Karpezo Iu. I. // Gidrobiol. zhurn. - 2010. - T. 46, No 5. - S. 75-89 (in Russian).

13. Oksiiuk O. P. Sanitarnaia gidrobiologiia v sovremennyy period. Osnovnye polozheniia, metodologiia, zadachi / Oksiiuk O. P., Davydov O. A. // Gidrobiol. zhurn. - 2012. - T. 48, No 6. - S. 50-65 (in Russian).

14. Semenchenko V. P. Printsipy i sistemy bioindikatsii tekuchikh vod / Semenchenko V. P. - Minsk: Orekh, 2004. - 125 s (in Russian).

15. Topachevs'kyy O. V. Vyznachnyk prisnovodnykh vodorostey Ukrains'koi RSR. KhI. Diatomovi vodorosti / Topachevs'kyy O. V., Oksiiuk O. P. - K.: Vyd-vo AN URSR, 1960. - 412 s (in Ukrainian).

16. Unifitsirovannye metody issledovaniia kachestva vod. Metody biologicheskogo analiza vod. - M.: SEV, 1977. - Pril. 1. Indikatory saprobnosti. - 91 s (in Russian).

17. Tsarenko P. M. Kratkiy opredelit' khlorokokkovykh vodorostey Ukrainskoy SSR / Tsarenko P. M. - Kiev: Nauk. dumka, 1990. - 208 s (in Russian).

18. Algae of Ukraine: diversity, nomenclature, taxonomy, ecology and geography / Ed. by P. M. Tsarenko, S. P. Wasser, E. Nevo. - Ruggell: Ganter Verlag, 2006-2011. (Vol. 1. Cyanoprokaryota, Euglenophyta, Chrysophyta, Xanthophyta, Raphidophyta, Phaeophyta, Dinophyta, Cryptophyta, Glaucocystophyta and Rhodophyta. - 2006. - 713 p.; Vol. 2. Bacillariophyta. - 2009. - 413 p.; Vol. 3. Chlorophyta. - 2011. 511 p.).

19. Bukhtiyarova L. Diatoms of Ukraine. Inland waters / Bukhtiyarova L. - Kyiv: National Academy of Science of Ukraine, 1999. - 133 p.

20. Davydov O. A. Ecologic and morphological structure of microphytobenthos in Verbnoe lake (Ukraine) / Davydov O. A. // Vseukrains'ka mizhnarodna konferentsiia «Aktual'ni problemy al'holohii. - Kyiv, 2019. S. 28-29.

21. Krammer, Lange-Bertalot H. Bacillariophyceae. 1 - 4 Teile. - In: Süsswasserflora von Mitteleuropa. - 2/1 - 4. - Stuttgart, Jena: VEB Gustav Fisher Verlag, 1986 - 1991. - 876; 596; 576; 437 S.

22. Sladeček V. System of water quality from the biological point of view / Sladeček V. // Ergebnisse der Limnologie. - 1973.- Vol. 7. - P. 1-128. 
O. A. Davydov, D. P. Larionova

Institute of Hydrobiology of NASU, Ukraine

\section{SANITARY AND HYDROBIOLOGICAL CHARACTERISTICS OF THE LAKE OF VERBNE ACCORDING TO MICROPHYTOBENTHOS}

Assessing ecological and sanitary state of aquatic ecosystems, including their trophic and saprobiological status and impact of human factors, is among key objectives in modern hydrobiology.

Apart from common hydrobiological methods (identifying species compositions, calculating algae number and biomass etc), there are specific methods for the assessment of aquatic ecosystems. Bioindication, which is based on aquatic organisms' response to environmental factors, including human factors, is the most important.

Microphytobenthos is highly sensitive to changes in natural and human factors. Its bioindication capabilities are widely known, therefore studying them as part of sanitary and hydrobiological characteristics of various water bodies is of great interest.

Water basins across the City of Kyiv are under diversified human impact including various factors and effects, which differ in pressure degree. Thus, using microphytobenthos for sanitary and hydrobiological assessment, even within one type of water basins, has certain aspects, which depend on the bottom algal communities' stability or degree of transformation. It is often caused by trophic and topic competition between microphytobenthos, phytoplankton and higher aquatic plants, as the latter two can inhibit growth of bottom algae.

In the view of the above, special attention should be paid to quantitative characteristics of benthonts, which may act as cenose-forming organisms. The paper examines the findings of the studies on microphytobenthos in Verbne Lake, which is affected by negative human factor contamination by surface and ground flow from Kyiv City area and is intensively used for recreation.

The objective is to study the sanitary and hydrobiological characteristics and ecological quality of Verbne Lake according to microphytobenthos' biondication indices.

Benthic algae were sampled with the MB-TE microbenthometer within the littoral zone in triplicate from the total area of $40 \mathrm{~cm}^{2}$. Algae number was calculated on a counting plate in a $0.1 \mathrm{~cm}^{3}$ drop, their biomass was calculated according to geometric similarity method. Trophic and saprobiological values were assessed in accordance with the scale, proven for microphytobenthos. Saprobity index was calculated according to the Pantle-Buck method in Sladecek modification on the grounds of traditional and modern data on saprobity indicator algae.

Benthonts, planktonts and periphytonts were distinguished with consideration taken of their association with particular habitats. Ecological classification of water quality was performed on the grounds of saprobity bioindication (saprobity indices) according to microphytobenthos. For microphytobenthos' structural components their role in species richness, number and biomass were analyzed.

Proceeding from the obtained findings, sanitary and hydrobiological characteristics of Verbne Lake were presented according to microphytobenthos. On the whole, the lake can be classified as mesotrophic, $\beta$-mesosaprobic water body. Benthonts proved to play an essential part in forming microphytobenthos' indicatory characteristics. Intensive phytoplankton growth in the water column and its sedimentation upon the lake bottom inhibit development of benthic algal forms. In accordance with the ecological water quality classification based on microphytobenthos saprobity bioindication results (saprobity indices), the water of Verbne Lake relates to Water Quality Class II, Water Quality Category 3. The most unfavorable situation within the lake's littoral area was registered in summer, which signals that self-purification processes are becoming less intensive and the aquatic ecosystem state is getting worse.

Key words: . microphytobenthos, bioindication, sanitary and hydrobiological characteristics, urban reservoir.

Надійшла 21.08.2019. 